\title{
Association of Cervical Screening Results with Colposcopic Findings
}

\section{Servikal Tarama Sonuçlarının Kolposkopik Bulgular ile İlişkisi}

\author{
(D) Derya Kılıç, (D) Tolga Güler
}

Pamukkale University Faculty of Medicine, Department of Obstetrics and Gynecology, Denizli, Turkey

\section{Abstract}

Objective: Cervical cancer is the fourth most common female cancer. In addition to early cancer diagnosis, the screening strategy of cervical cancer is based on early diagnosis of precancerous lesions [high-grade cervical lesions (HSIL)] to prevent cancer progression. The evaluation of clinical findings is very important for the monitoring and further modifications of the present cancer screening programs. This study aimed to review the relationship between the admission characteristics, human papilloma virus (HPV) types, Papanicolaou smear results and the colposcopic diagnoses of the patients who were referred for colposcopy.

Method: The characteristics and colposcopic diagnoses of 420 patients who were referred to a University Hospital between the years of 2016 and 2018 upon the detection of high-risk-HPV DNA positivity were evaluated retrospectively. The clinical properties, colposcopic findings, and sociodemographic features of the patients with HSIL and cancer were obtained through the file records.

Results: During the study period, 21 patients with carcinoma in situ and/ or cancer and 131 patients with HSIL had been diagnosed. When the patients with HSIL were analyzed, it was found that $76.3 \%(n=100)$ of the patients had HPV type 16 and/or 18 positivity, and $23.7 \%(n=31)$ of the patients had other types of high risk HPV positivity. Besides, it was observed that smear results were negative in approximately half of the cases ( $n=57,50.9 \%$ ). When different triage options to detect HSIL and above lesions were compared between each other, the highest sensitivity value $(92.11 \%)$ and the highest negative predictive value $(84.21 \%)$ were obtained by the triage of the patients with HPV 16 and/or 18 positivity and/or ASC-US and above. It was also observed that cytology alone was the triage method with the lowest sensitivity (30.92\%).

Conclusion: The results of the present study were compatible with the data of the current national cervical cancer screening program. Referring patients with HPV 16/18 and/or abnormal cytology to detect HSIL is a highly sensitive triage method. However, it should be considered that, even in this triage method, approximately $8 \%$ of the cases can be missed.

Keywords: Cervical cancer, human papilloma virus, screening, triage

\section{Öz}

\begin{abstract}
Amaç: Serviks kanseri en sık görülen dördüncü kadın kanseridir. Serviks kanserinin tarama stratejisi, erken kanser tanısına ek olarak kansere progresyonun önlenmesi amacıyla prekanseröz lezyonların [yüksek dereceli servikal lezyonlar (HSIL)] erken tanısı temelinde oluşturulmuştur. Klinik bulguların değerlendirilmesi, kanser tarama programının monitorizasyonu ve gelecekteki modifikasyonlar için oldukça önemlidir. Bu çalışmada kolposkopi için refere edilen hastaların başvuru özellikleri, insan papilloma virüsü (HPV) tipleri ve Papanicolaou smear sonuçları ile kolposkopik değerlendirme bulguları arasındaki ilişkinin değerlendirilmesi amaçlanmıştır.
\end{abstract}

Yöntem: 2016-2018 yılları arasında yüksek riskli HPV DNA pozitifliği saptanması üzerine bir üniversite hastanesine refere edilen toplamda 420 hastanın başvuru özellikleri ve kolposkopik tanıları retrospektif olarak değerlendirildi. HSIL ve kanser saptanan olguların sosyodemografik ve klinik özellikleri ile kolposkopi bulgularına dosya kayıtları üzerinden ulaşıldı.

Bulgular: Çalışma süresince hastaların 21 tanesinde kanser ya da karsinoma in situ, 131 tanesinde HSIL saptandı. HSIL saptanan olgular incelendiğinde, hastaların \%76,3'ünde $(n=100)$ HPV tip 16 ve/veya 18 pozitif olduğu ve hastaların \%23,7'sinde $(n=31)$ ise diğer yüksek riskli HPV pozitifliği olduğu izlendi. Yine bu olguların Pap smear sonuçları incelendiğinde olguların yaklaşık yarıında $(n=57, \% 50,9)$ smear sonucunun negatif olduğu izlendi. Kolposkopi için yönlendirilen tüm hastalarda, HSIL ve üzeri lezyonları yakalamak amacıyla uygulanabilecek diğer triyaj yöntemleri birbirleri ile karşılaştırıldığında; en yüksek sensitivite değeri $(\% 92,11)$ ve en yüksek negatif prediktif değer $(\% 84,21)$ HPV 16 ve/ veya 18 pozitifliği ve Pap smear sonucu ASCUS ve üzeri olguların triyajı ile elde edildi. Tek başına sitolojinin ise en düşük sensitiviteye $(\% 30,92)$ sahip triyaj yöntemi olduğu izlendi.

Sonuç: Çalışmamız güncel ulusal servikal kanser tarama programının verileri ile uyumludur. HSIL olgularının saptanabilmesi için HPV 16/18 ve/ veya anormal sitoloji saptanan hastaların refere edilmesi oldukça sensitif bir triyaj yöntemidir. Ancak bu triyaj yönteminde bile olguların yaklaşık \%8'inin atlanabileceği göz önünde bulundurulmalıdır.

Anahtar kelimeler: İnsan papilloma virüsü, servikal kanser, tarama, triyaj 


\section{Introduction}

Cervical cancer ranks fourth among all the female cancers in terms of both frequency and mortality (1). It is also a cancer type that can be prevented by vaccination and appropriate screening strategies. In addition to early cancer diagnosis, the screening strategy of cervical cancer is based on early diagnosis of precancerous lesions to prevent cancer progression. Approximately $99 \%$ of cervical cancers are associated with persistent high-risk Human papilloma virus (HPV) infections (2). And HPV infection test has been recommended by many professional associations, including the World Health Organization, European Union and US Preventive Services Task Force in the primary screening programs (3-5).

Turkey, as one of the leading countries in the world in this manner, adopted the HPV-based screening program in 2014 (5). According to the new early cancer diagnosis program, all cases with HPV 16 and HPV 18 infections or all cases with cytological abnormalities with other high-risk HPV (hrHPV) infections are referred for colposcopy. However, the data evaluating the relationship between the admission characteristics of high-grade intraepithelial lesion (HSIL) and cancer cases diagnosed after colposcopic evaluation following the primary screening still remain insufficient. The evaluation of this relationship is very important for the monitoring and further modifications of the cancer screening programs.

The present study aimed to review the relationship between admission characteristics and colposcopic evaluation results of the patients referred from cervical cancer screening program. The study also planned to evaluate the HPV types and Papanicolaou (Pap) smear results of the patients with cancer.

\section{Materials and Methods}

As a result of the early diagnosis of cancer program, the referral characteristics and colposcopic diagnoses of patients, who were referred to a university hospital between 2016 and 2018 upon the hrHPV DNA positivity, were evaluated retrospectively. Approval for the study was obtained from the Institutional Scientific Research Ethics Committee.

At the time of admission, the current hrHPV subtypes of patients were divided into three categories as HPV 16, HPV 18, and hrHPV-other. The Pap smear test results were classified as benign findings, atypical squamous cells with undetermined importance (ASCUS), atypical glandular cells, low grade intraepithelial lesion (LSIL), and HSIL at the time of admission. Colposcopic findings and final histopathological results were analyzed in three categories: benign findings, low grade squamous intraepithelial lesion/ LSIL (CIN I) and high-grade intraepithelial lesion/HSIL (CIN 2/3). The clinical properties, colposcopic findings, and sociodemographic features of the patients with HSIL and cancer were obtained through the file records.

In our clinic, all colposcopic examinations were performed through a binocular colposcope with 40 -fold magnification and a green filter feature connected to a digital screen. In accordance with our colposcopy application protocol, after washing the cervix with saline, it was scanned with a green filter for atypical vascularization, and then $3 \%$ acetic acid was applied to the cervix. After a one-minutelong application, the cervix was scanned for aceto-white appearance and stained with Lugol solution, and areas without Lugol involvement were noted. Biopsy was taken from suspicious areas, and the highest-grade lesion from biopsy results was evaluated as the pathology result of the patient.

\section{Statistical Analysis}

Descriptive values of quantitative continuous variables (such as age) were examined using the standard descriptive statistical methods (arithmetic mean, standard deviation, and median). Categorical variables (asset frequency) were presented with their frequencies and percentages. The evaluation of the quantitative measurements was carried out using the Student's t-test or the Wilcoxon signed rank test according to the distribution characteristics of the data. Comparisons of categorical variables were carried out using the chi-square or the Fischer's exact test, depending on the status of the case distributions. Cases with a $\mathrm{p}$ value of $<0.05$ were considered statistically significant.

\section{Results}

A total of 420 patients were referred to our unit for colposcopy during the study period. Among these patients, 21 cancer or carcinoma in situ and 131 HSIL were diagnosed histopathologically. The demographic data of these cases are presented in Table 1.

Only 3 (14.3\%) of the carcinoma in situ and cancer cases had abnormal LSIL as a result of the Pap smear test, and in $18(85.7 \%)$ cases, the Pap smear was reported either negative or inadequate. HPV 16 was detected in 18 (85.7\%) of 21 cases, while HPV 18 was detected in 4 (19\%) cases. In one case, HPV types 16 and 18 were observed together. 
The admission characteristics and histopathological and clinical diagnoses of in situ cancer or carcinoma cases are summarized in Table 2.

Examining the patients with HSIL, it was found that 100 (76.3\%) women had HPV type 16 and/or 18 positivity, and 31 (23.7\%) women had other hrHPV positivity. Examining the Pap smear results of these cases, it was observed that smear results were negative in approximately half of the cases $(n=57,50.9 \%)$. The admission characteristics of the cases with HSIL are presented in Table 3.

Table 1. Demographic characteristics of patients with high grade cervical lesion, carcinoma in situ and cancer

\begin{tabular}{llll} 
& HSIL & Ca in situ + Ca & p \\
\hline Age (mean \pm SD) & $43.08 \pm 8.48$ & $47.95 \pm 7.95$ & 0.019 \\
Parity (mean \pm SD) & $2.38 \pm 1.10$ & $2.33 \pm 1.11$ & 0.853 \\
Abortus (mean \pm SD) & $0.82 \pm 1.02$ & $1.40 \pm 1.14$ & 0.021 \\
$\begin{array}{l}\text { Number of partners } \\
\text { (mean } \pm \text { SD) }\end{array}$ & $1.21 \pm 0.50$ & $1.05 \pm 0.21$ & 0.161 \\
Menopausal status & & & \\
Premenopause [n (\%)] & $97(74 \%)$ & $12(57.1 \%)$ & 0.182 \\
Postmenopause [n (\%)] & $34(26 \%)$ & $9(42.9 \%)$ & \\
\hline HSIL: High grade cervical lesion, Ca: Cancer; n: number, SD: Standard deviation
\end{tabular}

Table 2. Screening features and presentation of the cases with invasive or in situ cancer

\begin{tabular}{lllll}
$\begin{array}{l}\text { Patients' } \\
\text { number }\end{array}$ & Age & $\begin{array}{c}\text { HPV } \\
\text { type }\end{array}$ & Pap smear & Diagnoses \\
1 & 33 & 18 & Negative & Adeno Ca \\
2 & 38 & 16 & Negative & Invaziv SCC \\
3 & 38 & 16 & Negative & Microinvasive SCC \\
4 & 40 & 16 & Inadequate & Invasive SCC \\
5 & 42 & 16 & Inadequate & Microinvasive SCC \\
6 & 43 & 16 & Inadequate & Microinvasive SCC \\
7 & 45 & 16 & LSIL & Microinvasive SCC \\
8 & 46 & 16 & LSIL & Adenoca Insitu \\
9 & 46 & 16 & Negative & Adenoca Insitu \\
10 & 47 & 16 & Negative & Invasive SCC \\
11 & 48 & 18 & Negative & Invasive SCC \\
12 & 50 & 16 & Negative & Microinvasive SCC \\
13 & 50 & 16 & Negative & Microinvasive SCC \\
14 & 52 & 16 & Negative & Invasive SCC \\
15 & 53 & 18 & Inadequate & Microinvasive SCC \\
16 & 54 & 16 & LSIL & Microinvasive SCC \\
17 & 59 & 16 & Negative & Invasive SCC \\
18 & 60 & 16 & Inadequate & Adeno Ca \\
19 & 60 & 16 & Negative & Invasive SCC \\
20 & 61 & 16 & Inadequate & Adenoca Insitu \\
21 & 42 & 16,18 & Negative & Invasive SCC \\
\hline $5 C$ ind & & & &
\end{tabular}

SCC: squamous cell carcinoma; Ca: cancer; LSIL: low grade cervical intraepithelial lesion, HPV: Human papilloma virus, Pap: Papanicolaou
Examining the HPV type 16/18 status of the patients, it was seen that in HPV type 16 positive patients were determined in $84(64.12 \%)$ while HPV type 18 patients were detected only in $12(0.9 \%)$ of the total patients. In 4 of the patients, both HPV type 16 and HPV type 18 were found to be positive.

Comparing all triage methods that could be applied to all patients referred for colposcopy to detect HSIL-and-above lesions between each other, the highest sensitivity value $(92.11 \%)$ and the highest negative predictive value $(84.21 \%)$ were obtained with the triage of HPV 16 and/or 18 positivity and hrHPV positivity with ASCUS-and-above Pap smear test results. It was observed that cytology was the sole triage method with lowest sensitivity (30.92\%). The sensitivity and specificity values of the different triage protocols are given in Table 4.

\section{Discussion}

In this study, 420 patients who were referred for colposcopy as a result of screening were evaluated, and a total of 8 invasive cancer, 8 microinvasive cancer, 2 adenocarcinoma and 3 adenocarcinoma in situ cases were detected. In only three of these cases, the Pap smear results were reported as LSIL, and remarkably, in all other cases, the Pap smear result was found to be negative or inadequate. The HPV type 16 was detected in all of these cases. These results confirm the superiority of HPV screening to Pap smear screening in cervical cancer screening. Also, these results indicate that even if the smear screening is negative, a colposcopic evaluation of patients with HPV 16 is required.

In the monitorization of the cervical cancer screening program, the examination of detected high-grade lesions and cancers is an important parameter. Interestingly, HPV screening histopathologically revealed HSIL in $23.7 \%$ of the cases with high-risk types other than 16-18. As a result of

Table 3. Human papilloma virus and papanicolaou smear results of the patients who had high grade cervical lesions

\begin{tabular}{llll} 
& & $\mathbf{n}$ & \% \\
\hline HPV & Type 16 and/or 18 & 100 & 67.2 \\
\multirow{3}{*}{ Smear } & Other hrHPV types & 31 & 23.7 \\
& Inadequate & 33 & 25.2 \\
& Negative & 17 & 13 \\
& ASCUS & 8 & 6.1 \\
& LSIL & 31 & 23.7 \\
& HSIL & 2 & 1.5 \\
\hline
\end{tabular}

HPV: Human papilloma virus, ASCUS: Atypical squamous cells with undetermined importance, LSIL: Low grade cervical lesions, HSIL: High grade cervical lesions, hrHPV: High risk human papilloma virus 
Table 4. Diagnostic evaluation of different triage protocols

\begin{tabular}{|c|c|c|c|c|c|c|c|c|}
\hline & \multicolumn{2}{|c|}{ HPV 16/18 } & \multicolumn{2}{|c|}{ ASCUS+ cytology } & \multicolumn{2}{|c|}{ HPV16/18 or ASCUS+ } & \multicolumn{2}{|c|}{ HPV16/18 or LSIL+ } \\
\hline & Value & $95 \% \mathrm{Cl}$ & Value & $95 \% \mathrm{Cl}$ & Value & $95 \% \mathrm{Cl}$ & Value & $95 \% \mathrm{Cl}$ \\
\hline Sensitivity & $79.61 \%$ & $72.32-85.70 \%$ & $30.92 \%$ & $23.68-38.92 \%$ & $92.11 \%$ & $86.62-95.85 \%$ & $88.16 \%$ & $81.93-92.83 \%$ \\
\hline PPV & $46.18 \%$ & $42.75-49.66 \%$ & $35.07 \%$ & $28.71-42.02 \%$ & $40.70 \%$ & $38.74-42.68 \%$ & $40.61 \%$ & $38.38-42.87 \%$ \\
\hline NPV & $80.38 \%$ & $74.49-85.18 \%$ & $63.29 \%$ & $60.10-66.36 \%$ & $84.21 \%$ & $74.85-90.53 \%$ & $80.00 \%$ & $71.29-86.56 \%$ \\
\hline
\end{tabular}

HPV: Human papilloma virus, ASCUS: Atypical squamous cells of undetermined significance, LSIL: Low grade squamous epithelial lesions, PPV: Positive predictive value, NPV: Negative predictive value, Cl: Confidence interval

the evaluation following the collection of the prospective follow-up results of these cases, the risks of HPV types in terms of pre-invasive and invasive cancer can be evaluated more precisely and modifications may be evaluated for the screening program.

Cervical cancer ranks fourth among all the cancer cases seen in women (1). However, almost all cervical cancers can be prevented with early diagnosis and vaccination programs (6). To adopt a more effective screening program, Turkey launched the National Cancer HPV-based screening program in 2014. In the fourth year of the new screening program, Gultekin et al. (4) published the patient data of one million cases reported in Turkey. In these data, it was reported that HPV positivity was found in $3.5 \%$ of all women who participated in the screening program and $1.6 \%$ of these patients were referred to colposcopy (5).

The examination of the data from Turkey showed that if the screening was carried out only with the Pap smear test, HSIL and/or cancer would have been missed in $45.9 \%$ of the cases. Then, Gultekin et al. (7), in a very recent study, have shared the data of four million patients in Turkey. According to this study, for the HPV-positive women, cytology has been reported as normal in $69.2 \%$ and as inadequate in $16.6 \%$. The positive predictive value of triage was found to be $26.4 \%$ with sole Pap smear test. It has been also stated that, besides HPV types 16 and 18, some other types of hrHPV infections may also be important in HSIL cases. This result also brings the extended genotype triage system into question. Similarly, in the present study, the rate of HSIL associated with other HPV types was found to be $23.7 \%$.

Using the Pap smear method for scanning has scientific and organizational problems (8). The main problem is low sensitivity and high false negativity in capturing cases with HSIL and above. Also, Pap smear tests are not accurate in detecting adenocarcinoma. Similarly, in the present study, of the adenocarcinomas in situ and adenocarcinoma cases, only one had abnormal smear results during screening. Also, the maintenance and installation of cytology-based screening programs are very difficult. HPV DNA testing, on the other hand, is more advantageous as the screening test with its lack of complex quality standards, allowing long scanning intervals, the ease of application, and objectivity (9).

In a recent systematic review comparing cytology and HPV-based screening in the cervical cancer screening program, covering the research carried out between 1992 and 2015, approximately 40 studies examining more than 140,000 women were evaluated (10). In the review, HPV tests and cytological evaluation were compared with different thresholds. The authors reported that the rate of false negativity of cytology in detecting CIN 2 and above lesions was quite high compared to the HPV test. In the present study, in accordance with this result, the sensitivity value of cytology was found to be very low $(30.92 \%)$ only in detecting CIN 2 and above lesions. However, with the addition of HPV tests to cytology, this rate increased to $92.11 \%$. In the present study, when LSIL was accepted as the cytological threshold value instead of ASCUS, it was seen that the sensitivity decreased (88.16\%) although there was no significant increase in the specificity values.

With the Addressing the Need for Advanced HPV Diagnostics study $(11,12)$, cervical precancerous lesions were found to be more common in patients with high-prevalence HPV 16 and/or HPV 18 cases compared to other high-risk HPVs. Although the importance of detecting other HPV genotypes is not clearly demonstrated, current guidelines recommend performing colposcopy for patients with positive HPV DNA if their cytology is abnormal in women over 30 years of age (3). Evaluating the recent studies, it was seen that the cancer rate varied between $0.6 \%$ and $9.3 \%$ in HPV type 16 or 18 positive cases $(12,13)$. In the present study, HPV 16 and/or HPV 18 were detected in all 21 cancer cases. However, only 
three of the cases had abnormal smear results. Examining the CIN 3 cases, almost one fourth of the HSIL cases had another hrHPV positivity. In 12 of these 31 cases, cytology result was reported as normal or inadequate.

Examining the data containing four million women in Turkey, in addition to HPV 16/18 cases, HPV types 33, 31, 35 and 45 were also regarded as important HPV types (7). For all these subtypes, in this study, The HPV DNA analysis was reported to show a positive predictive value exceeding $10 \%$ for HSIL. There are similar studies that are in line with this result $(14,15)$. Extensive studies are required to determine the relationship of HPV infection other than HPV type 16/18 with wide genotyping and HSIL and above lesions. On the other hand, in line with the results of the present study, the positive predictive value of the Pap smear test did not change according to the choice of the threshold as LSIL or ASCUS. This was associated with knowing the initial HPV values during cytology screening and performing the cytology screening in high quality central laboratories.

Other than the basic sociodemographic data of the patients, the inability to include detailed clinical data in the analysis and its retrospective design were the limitations of the present study. The fact that the study was a single-center study and the number of patients were the strengths of our study.

\section{Conclusion}

The results of the present study were compatible with the data of the current cervical cancer screening program. The results also indicated that HPV screening was more sensitive in cervical cancer screening compared to Pap smear screening. Referencing patients with HPV 16/18 and/or abnormal cytology to detect HSIL cases in patients is a highly sensitive triage method. However, it should be considered that, even in this triage method, approximately $8 \%$ of the cases can be missed.

\section{Ethics}

Ethics Committee Approval: Approval for the study was obtained from the Institutional Scientific Research Ethics Committee (date 16/04/020, number: 60116787020/26602).

Informed Consent: Verbal consent was obtained from all patients.

Peer-review: Externally peer-reviewed.

\section{Authorship Contributions}

Concept: D.K., T.G., Design: D.K., T.G., Data Collection or Processing: D.K., T.G., Analysis or Interpretation: D.K., T.G., Writing: D.K.

Conflict of Interest: No conflict of interest was declared by the authors.

Financial Disclosure: The authors declared that this study has received no financial support.

\section{References}

1. Bray F, Ferlay J, Soerjomataram I, Siegel RL, Torre LA, Jemal A. Global cancer statistics 2018: GLOBOCAN estimates of incidence and mortality worldwide for 36 cancers in 185 countries. CA Cancer J Clin 2018;68:394-424.

2. Arbyn M, Ronco G, Anttila A, Meijer CJLM, Poljak M, Ogilvie G, et al. Evidence regarding human papillomavirus testing in secondary prevention of cervical cancer. Vaccine 2012;30(Suppl 5):F88-99.

3. Screening for Cervical Cancer: US Preventive Services Task Force Recommendation Statement I Cancer Screening, Prevention, Control I JAMA I JAMA Network. Available from: https:// jamanetwork.com/journals/jama/fullarticle/2697704

4. Gultekin M, Zayifoglu Karaca M, Kucukyildiz I, Dundar S, Boztas G, Semra Turan H, et al. Initial results of population based cervical cancer screening program using HPV testing in one million Turkish women. Int J Cancer 2018;142:1952-1958.

5. 2012 updated consensus guidelines for the management of abnormal cervical cancer screening tests and cancer precursors. - Abstract - Europe PMC [Internet]. [cited 2020 May 25]. Available from: https://europepmc.org/article/med/23519301

6. Ronco G, Dillner J, Elfström KM, Tunesi S, Snijders PJF, Arbyn M, et al. Efficacy of HPV-based screening for prevention of invasive cervical cancer: follow-up of four European randomised controlled trials. Lancet 2014;383(9916):524-532.

7. Gultekin M, Zayifoglu Karaca M, Kucukyildiz I, Dundar S, Boztas G, Turan HS, et al. Initial results of population based cervical cancer screening program using HPV testing in one million Turkish women. Int J Cancer 2018;142:1952-1958.

8. Safaeian M, Sherman ME. From Papanicolaou to Papillomaviruses: Evolving Challenges in Cervical Cancer Screening in the Era of Human Papillomavirus Vaccination. J Natl Cancer Inst 2013;105:1524-1526.

9. von Karsa L, Arbyn M, De Vuyst H, Dillner J, Dillner L, Franceschi S, et al. European guidelines for quality assurance in cervical cancer screening. Summary of the supplements on HPV screening and vaccination. Papillomavirus Res 2015;1:22-31.

10. Koliopoulos G, Nyaga VN, Santesso N, Bryant A, Martin-Hirsch PP, Mustafa RA, et al. Cytology versus HPV testing for cervical cancer screening in the general population. Cochrane Database Syst Rev 2017;8:CD008587.

11. Wright TC, Stoler MH, Behrens CM, Apple R, Derion T, Wright TL. The ATHENA human papillomavirus study: design, methods, and baseline results. Am J Obstet Gynecol 2012;206:46.e1-46. el1. 
12. Monsonego J, Cox JT, Behrens C, Sandri M, Franco EL, Yap PS, et al. Prevalence of high-risk human papilloma virus genotypes and associated risk of cervical precancerous lesions in a large U.S. screening population: data from the ATHENA trial. Gynecol Oncol 2015;137(1):47-54.

13. Lagos M, Van De Wyngard V, Poggi H, Cook P, Viviani P, Barriga MI, et al. HPV16/18 genotyping for the triage of HPV positive women in primary cervical cancer screening in Chile. Infect Agents Cancer 2015;10:43.
14. Adcock R, Cuzick J, Hunt WC, McDonald RM, Wheeler CM, New Mexico HPV Pap Registry Steering Committee. Role of HPV Genotype, Multiple Infections, and Viral Load on the Risk of HighGrade Cervical Neoplasia. Cancer Epidemiol Biomarkers Prev 2019;28(11):1816-1824.

15. Cuzick J, Wheeler C. Need for expanded HPV genotyping for cervical screening. Papillomavirus Res 2016;2:112-115. 